\title{
The Baltic countries towards the goals of waste framework directive
}

\author{
Natālija Cudečka-Puriņa, Lilita Ābele, Dzintra Atstāja, Liepaja University \\ Vladimirs Cudečkis, Riga Technical University
}

\begin{abstract}
Social acceptance of littering behaviour has changed in the recent decades, with rapidly increasing public awareness about the human health and biodiversity impacts that can result from waste-mismanagement. Littering has an important impact on landscape and overall environment. It is of vital importance to assess existing littering sources and to try to limit them at their source. During recent years European Union (EU) has significantly strengthened the waste management requirements. In terms of newer Member States it meant - inventory of the existing system, closure and recultivation of the sub-standard landfills, development of new infrastructure, using best available technologies and, of course implementation and development of separate waste collection system. In order to ensure higher quality recycling, requirements to sorted waste collection become higher. The authors see one of the solutions - implementation of the deposit refund system (DRS), especially taking into account that both plastic beverage bottles as well as bottle caps have been identified within top 10 single use plastic found in the marine litter. The research is based on the benchmarking and statistical data analysis. As the result of the research, the authors propose implementation of DRS as a solution both to Latvian waste management issues and as a tool to improve landscape from the environmental aspects.
\end{abstract}

Key words: deposit refund system, waste management, waste recycling

\section{Introduction}

Good waste management is a building block of the circular economy and helps prevent waste from having a negative impact on the environment and health. Social acceptance of littering behaviour has changed in the recent decades, with rapidly increasing public awareness about the human health and biodiversity impacts that can result from wastemismanagement [27]. Proper implementation of the EU's waste legislation will speed up the transition to a circular economy. There are essentially two varieties of legislation used to reduce waste in the environment. These include "command and control" measures, and market-based economic instruments [22].

Legal obligations on the management of municipal waste (waste from households and similar waste) are laid down in the Waste Framework Directive [9]. The Directive includes two recycling and recovery targets to be achieved by 2020: $50 \%$ preparing for reuse and recycling of certain waste materials from households and other origins similar to households, and $70 \%$ preparing for re-use, recycling and other recovery of construction and demolition waste. Although, the Directive has been adopted 10 years ago, providing 2 years for Member States for transposition, the analysis of municipal waste recycling ratios shows that many Member States still have this target as a very challenging issue.

From the table 1 it may be seen that 5 member states have the recycling rate above $50 \%$ and 9 member states are in a so called risk-free zone of above $42 \%$, meaning that these countries most probably will be able to achieve 2020 target. Still 14 member states are at risk of non-achieving the targets, which may result in considerably high penalties [7].
Although, it has to be noted, that the authors critically evaluate the data provided by Eurostat, taking into account that the data is calculated using one out of four calculation methods. As soon as the Member states will unify the calculation methods, the figures are about to change. It is important to point out, that Latvia is already using the calculation method that will be used in the future. In addition, Latvia's figure might improve in case Eurostat will count in the "recovery" of waste within biological reactor. In this case the recycling figure will be $62 \%$. The authors would like to point out that the high recycling ratios by Lithuania and Slovenia for instance are mostly due to implementation of incineration with energy recovery. In 2016, Europeans generated on average $480 \mathrm{~kg}$ of municipal waste per person, $46 \%$ of which was recycled or composted, while a quarter was landfilled [10]. Taking into account that in May 2018 European commission adopted amendments to the Waste package directives, new and ambitious targets on waste treatment are set in front of the member states. In addition, European Commission published a Proposal for a Directive on the reduction of the impact of certain plastic products on the environment. Single Use Plastic items represent about half of all marine litter items found on European beaches by counts. The 10 most found SUP items represent $86 \%$ of all SUP items (constituting thus $43 \%$ of all marine litter items found on European beaches by count).

Beverage bottles that are single-use plastic products are one of the most found marine litter items on the beaches in the Union. This is due to ineffective separate collection systems and low participation in those systems by the consumers. It is necessary to 
TABLE 1

Municipal waste recycling rates, 2017 [10]

\begin{tabular}{|l|l|l|l|}
\hline Country & $\begin{array}{l}\text { Recycling } \\
\text { rate }(\%)\end{array}$ & Country & $\begin{array}{l}\text { Recycling } \\
\text { rate }(\%)\end{array}$ \\
\hline Germany & 67.6 & Bulgaria & 36.2 \\
\hline Austria & 57.6 & Hungary & 35 \\
\hline Slovenia & 57.8 & $\begin{array}{l}\text { Czech } \\
\text { Republic }\end{array}$ & 34.1 \\
\hline Netherlands & 54.2 & Poland & 33.8 \\
\hline Belgium & 53.7 & Spain & 33.5 \\
\hline Luxembourg & 48.3 & Portugal & 30.9 \\
\hline Lithuania & 48.1 & Slovakia & 29.8 \\
\hline Sweden & 46.8 & Estonia & 28.1 \\
\hline Denmark & 46.3 & Latvia & 25.2 \\
\hline EU 28 & 45.3 & Croatia & 23.5 \\
\hline Italy & 45.1 & Greece & 17.2 \\
\hline $\begin{array}{l}\text { United } \\
\text { Kingdom }\end{array}$ & 44.3 & Cyprus & 16.1 \\
\hline France & 42.9 & Romania & 13.9 \\
\hline Finland & 42.0 & Malta & 6.4 \\
\hline
\end{tabular}

promote more efficient separate collection systems and therefore, a minimum separate collection target should be established for beverage bottles that are single-use plastic products. Member States should be able to achieve that minimum target by setting separate collection targets for beverage bottles that are single-use plastic products in the framework of the extended producer responsibility schemes or by establishing deposit refund schemes or by any other measure that they find appropriate. This will have a direct, positive impact on the collection rate, the quality of the collected material and the quality of the recyclates, offering opportunities for the recycling business and the market for the recyclate. The Directive requires Member States to achieve a minimum separate collection target for single- use plastic beverage bottles. The latest wording of the article foresees that Member States shall take the necessary measures to collect separately for recycling: a) no later than by $202575 \%$ of single-use PET bottles placed on the market and b) no later than by $203090 \%$ of single-use PET bottles placed on the market. Thus, European Commission is setting ambitious targets, leading Member states to depositrefund system, as it has been discussed that efficient sorted waste collection system could reach approximately $75 \%$ of separate collection for PET material. According to Eunomia [5], DRS can ensure $95 \%$ reduction in littering of beverage containers, which could positively impact the SUP restriction into the landscapes and marine environment. As beverage containers are often consumed on the go (and are significantly larger than frequently-littered items such as cigarette butts or chewing gum), it is estimated that, generally, they account for approximately $40 \%$ of litter by volume. The deposit attached to beverage containers gives them a financial value, so consumers will be less likely to litter them. When beverage containers are littered, other citizens will be motivated to pick them up so that they can claim the refund. As such, it is estimated that a well-designed DRS could reduce the littering of beverage containers by $95 \%$, meaning the volume of all litter would reduce by a third [6].

\section{Materials and Methods}

This study is focused on the assessment of European and in particular Baltic countries in terms of municipal waste recycling, further focusing on packaging waste. Taking into account the latest developments of the legislative proposals by the European Commission, the authors see the DRS as one option to ensure the achievement of the ambitious targets set for the Member states to achieve. The research is based on statistical data analysis and benchmarking. Taking into consideration that Latvia has still not implemented the DRS, it is of vital importance to evaluate the experience of neighbouring countries in order to develop the most appropriate model, taking into account best experiences from the countries, which already have DRS in place.

\section{Results and Discussion}

As the problem of marine litter has steadily grown worse, there has been renewed interest in depositreturn for the recovery of single-use beverage containers. These systems see customers pay a small deposit when they purchase a can or bottle, which they get back when they return the container to a collection point for recycling [25]. In deposit-refund systems, consumers pay a deposit when purchasing products and receive refunds when returning used products. Deposit-refund systems are introduced to increase the return rates, partly achieved by paying consumers incentives to return their used products to appropriate places [21]. According to Linderhof, et.al. [19] and Walls [29], deposit-refund schemes are basically a combination of two instruments: a tax on the purchase of a certain product, and a subsidy on the separate collection of the same product in its after-use stage. They can be efficient policy instruments to encourage reuse and recycling.

\section{DRS - a tool to decrease the environmental life cycle impact of beverage packaging and to increase its resource efficiency}

When assessing DRS, it has to be emphasised, that in the European Union currently there are 9 member states which have DRS in place, the newer countries to introduce the system are Lithuania in 2016, Italy in 2017 a range of countries, including Latvia are currently at the evaluation or implementation stage. Table 2 reveals summary in DRSs across EU. According to Reloop [25] and Lavee [18] deposit return systems are a proven tool to collect high quantities of empty beverage containers for reuse and 
Implementation of DRS in EU. Created by the authors

\begin{tabular}{|c|c|c|c|}
\hline $\begin{array}{c}\text { Country } \\
\text { (MS } \\
\text { since) }\end{array}$ & $\begin{array}{c}\text { Mandatory } \\
\text { DRS }\end{array}$ & $\begin{array}{c}\text { Country } \\
\text { (MS since) }\end{array}$ & DRS \\
\hline $\begin{array}{c}\text { Belgium } \\
(1958)\end{array}$ & Yes (2002) & $\begin{array}{c}\text { Slovakia } \\
(2004)\end{array}$ & $\begin{array}{c}\text { Under } \\
\text { evaluation }\end{array}$ \\
\hline $\begin{array}{c}\text { Croatia } \\
(2013)\end{array}$ & Yes (2005) & $\begin{array}{c}\text { United } \\
\text { Kingdom } \\
(1973)\end{array}$ & $\begin{array}{c}\text { Under } \\
\text { evaluation }\end{array}$ \\
\hline $\begin{array}{c}\text { Denmark } \\
(1973)\end{array}$ & Yes (2002) & $\begin{array}{c}\text { Austria } \\
(1995)\end{array}$ & N/a \\
\hline $\begin{array}{c}\text { Estonia } \\
(2004)\end{array}$ & Yes (2005) & $\begin{array}{c}\text { Bulgaria } \\
(2007)\end{array}$ & N/a \\
\hline $\begin{array}{c}\text { Finland } \\
(1995)\end{array}$ & Yes (1996; & $\begin{array}{c}\text { Cyprus } \\
(2004)\end{array}$ & N/a \\
\hline $\begin{array}{c}\text { Germany } \\
(1958)\end{array}$ & Yes (2003) & $\begin{array}{c}\text { France } \\
(1958)\end{array}$ & N/a \\
\hline $\begin{array}{c}\text { Lithuania } \\
(2004)\end{array}$ & Yes (2016) & $\begin{array}{c}\text { Greece } \\
(1981)\end{array}$ & N/a \\
\hline $\begin{array}{c}\text { Netherlan } \\
\text { ds (1958) }\end{array}$ & $\begin{array}{c}\text { Yes (1993; } \\
\text { 2006) }\end{array}$ & $\begin{array}{c}\text { Hungary } \\
(2004)\end{array}$ & N/a \\
\hline $\begin{array}{c}\text { Finland } \\
(1995)\end{array}$ & Yes (1996; & $\begin{array}{c}\text { Luxembour } \\
\text { g (1958) }\end{array}$ & N/a \\
\hline $\begin{array}{c}\text { Sweden } \\
(1995)\end{array}$ & $\begin{array}{c}\text { Yes (1984; } \\
1994)\end{array}$ & $\begin{array}{c}\text { Malta } \\
(2004)\end{array}$ \\
\hline $\begin{array}{c}\text { Czech } \\
\text { Republic } \\
(2004)\end{array}$ & $\begin{array}{c}\text { Under } \\
\text { evaluation }\end{array}$ & $\begin{array}{c}\text { Poland } \\
(2004)\end{array}$ \\
\hline $\begin{array}{c}\text { Ireland } \\
(1973)\end{array}$ & $\begin{array}{c}\text { Under } \\
\text { evaluation }\end{array}$ & $\begin{array}{c}\text { Portugal } \\
(1986)\end{array}$ \\
\hline $\begin{array}{c}\text { Italy } \\
(1958)\end{array}$ & $\begin{array}{c}\text { Under } \\
\text { evaluation }\end{array}$ & $\begin{array}{c}\text { Romania } \\
(2007)\end{array}$ \\
\hline $\begin{array}{c}\text { Latvia } \\
(2004)\end{array}$ & $\begin{array}{c}\text { Under } \\
\text { evaluation }\end{array}$ & $\begin{array}{c}\text { Slovenia } \\
(2004)\end{array}$ & N/a \\
\hline
\end{tabular}

high-quality recycling and are vital to achieving circular economy. Over 130 million people in the EU alone live in countries with deposit-systems. It's also

used in most Canadian provinces, 10 US states, and large portions of Australia. The latest jurisdiction to implement a container deposit program was New South Wales in 2017. A range of studies have performed the assessment of economic aspects of depositrefund system [4, 20], in addition, there are also studies performing analysis of impact from packaging deposit-refund system on consumers and producers [17].

Both the strategy on the prevention and recycling of waste $[1,8,30]$ and the strategy on the sustainable use of natural resources aim for a reduction of the European economy's environmental impact and an increase of its resource efficiency. Within this, DRS aim at increasing the proportion of empty packaging returned by consumers to take-back/collection points. This helps to increase the reuse of packaging products and the recycling of packaging material. It also provides inhabitants with a tangible incentive to participate in waste prevention processes $[14,28]$.
Community law leaves it to each Member State to choose between a deposit and return system, on the one hand, and a global packaging-collection system on the other, or to opt for a combination of the two systems depending on the type of product [7].

As clearly demonstrated in Figure 1 countries, which have a mandatory deposit system, have achieved significantly higher recycling rates than member states without such a system in place. Still, it is quite complicated to compare EU member state achievements as DRS exist on reusable containers, one-way containers, metal cans, etc. Moreover the DRS in the Member states distinguish by being voluntary or mandatory, for example, as stated by Hassi, Pietkäinen [16], in Finland the return rate of drink containers increased by $15 \%$ between 2008 and 2009 in connection with the introduction of a mandatory DRS. The percentage of returned plastic bottles in 2009 was $89 \%$, for aluminium cans $92 \%$ and for glass bottles - $98 \%$ [3]. The very significant increase in the actual number of cans returned whilst the return rate remains relatively steady reflects the change in consumption patterns from refillable glass bottles to one-way cans. Refillable glass bottles are returned at an even higher rate than one-way packaging. In 2014, the rate was $97 \%$, and in 2015 it was $98 \%$. It is noted that Finland's significant shift from refillable to one-way beverage packaging over the last ten years or so has been attributed to the structure of the packaging tax, which stimulated the use of refillable packaging over one-way packaging until amended in 2004 and again in 2008 [23].

Latest plastics recycling data (see Fig. 1) shows that the Member states have results varying from almost $75 \%$ to $25 \%$ recycling. It is important to stress, that for example Lithuanian figures can be explained by the fact that prior 2016 Lithuania had implemented sorted waste collection and with the implementation of DRS the recycling ratios have improved significantly. On the other hand, the case of Estonia shows that only relying on DRS with weak initial development of sorted waste collection is not facilitating to reach 2025 target.

It has to be stressed that, despite the fact that the amount of deposit on one-way packaging in European Union member states applying a mandatory deposit system varies from 0.04 EUR in Estonia (in 2005) and now Croatia having the lowest fee of 0.07 EUR to 0.40 EUR in Finland and Denmark, when broadening the analysis worldwide, the refund figures are close, varying from 0.03 EUR in some states of the USA to 0.27 EUR in Canada. Economical incentive definitely stimulates return rate escalation, thus additional research is planned by the author in the future to examine the savings of the inhabitants at the expense of waste collection costs. The countries with mandatory deposit systems show an average $82.42 \%$ 


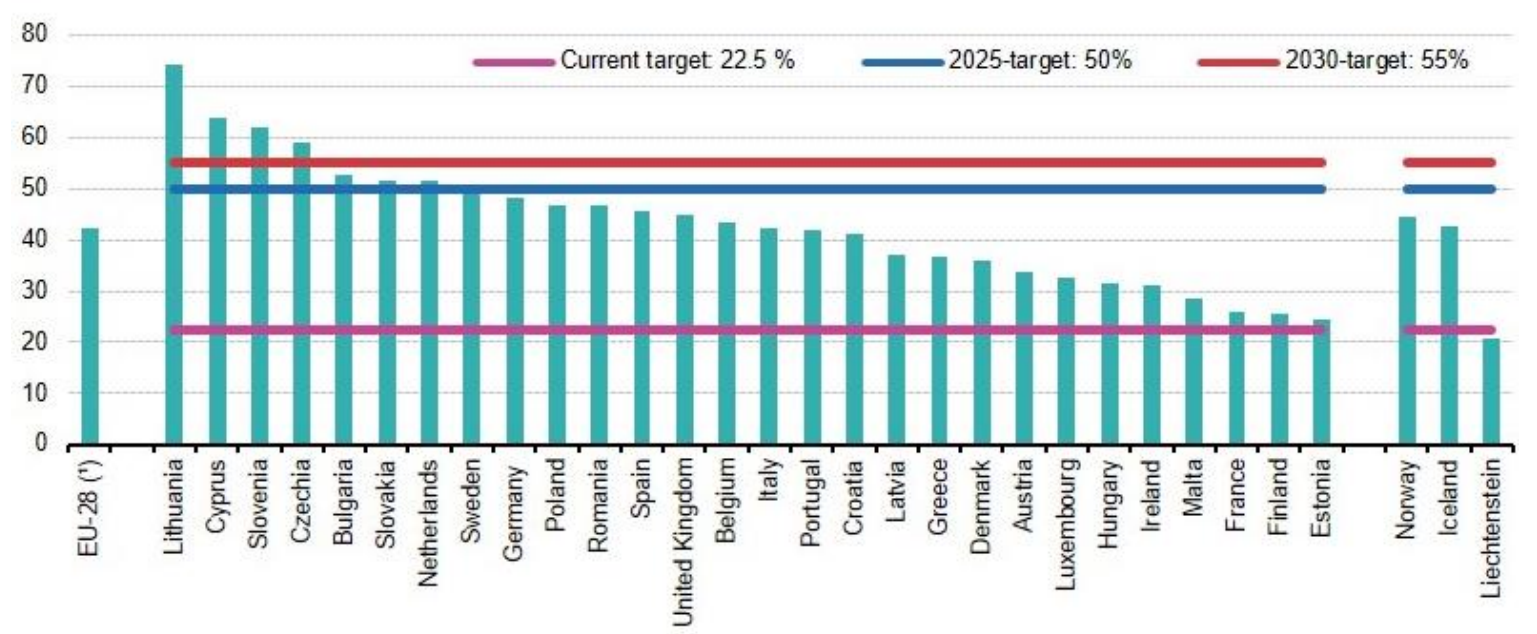

Fig. 1. Recycling rate for plastic packaging in 2016 in EU [10].

return rate, which is a very high and challenging achievement. The member states without mandatory DRS cannot impress the statistics with such return rate figures $[2 ; 25 ; 26]$.

Some countries (including Latvia) struggle for decades to implement DRS due to the unwillingness of retailers to participate in the scheme and due to waste management companies which state that they would be deprived of part of their profit and argue that current waste management system with waste containers for separate waste collection (paper/cardboard, glass, PET bottles) would become ineffective. Of course, this is clearly founded on economics, as for example a waste management company, collecting sorted waste can have a revenue of approx. $20 \mathrm{EUR} / \mathrm{t}$ for glass and at the same time almost 250 EUR/t for PET material [24; 15]. Nonetheless there are examples of successful deposit systems which exist together with sorted waste collection, for example - Germany, Austria, the Netherlands. Thus it is planned to perform a more indepth analysis of trends and retrospective in sorted waste collection and DRS. Application of a complex solution can obviously bring better results in reaching recovery and recycling targets. One important aspect with the DRS - is the implementation costs. It has been proven that the implementation of the system at the earlier stage of waste management development often results more economically efficient and cheaper than at the later stages. According to Dace, et.al. [12] the costs of the deposit-refund system depend on the amount of packaging placed on the market. The amount of deposit packaging, in its turn, depends on the consumption of beverage drinks affected by GDP. Implementation of DRS brings benefits such as increase in the return rate, increase in recycling rate, and better quality of collected materials, less waste in the environment. Thus it does have high initial infrastructural investment costs and many countries do experience strong lobby from retailers, and from waste management companies engaged in collection of sorted waste.

The introduction of mandatory DRSs nevertheless may be justified if the environmental/economic benefits clearly surpass their direct and indirect costs. There, however, are options for removing the trade barriers by harmonising the national DRSs [14]. In support of the abovementioned, there are examples of transboundary flow of one-way beverage cans among Germany, Denmark, Sweden, Norway and Finland. The problem here is that cans, purchased in Germany are not covered by the German or the Danish DRS [2,4]. On the other hand there is an example of neighbouring countries - Latvia and Estonia, whereby when the latter implemented DRS, Latvian citizens from the cities and villages in Latvia closest to Estonia started bringing PET bottles to Estonian DRS, so Estonia had to protect their system in order to accept only packaging purchased in Estonia [11].

Table 3 provides a comparison of packaging recycling rates and deposit refund fee. The figures achieved are the result of the high return rate.

\section{Benefits and drawbacks of deposit-refund system}

When analysing the differences within the countries with and without deposit-refund system, the authors were able to get certain evidence from other countries that well-designed and well-run DRS can deliver an estimated increase of around $20 \%$ in the reported amount of beverage containers collected for recycling, and deliver a better quality of captured material (i.e., less contamination) than is currently estimated as happening in the countries without DRS for beverage packaging [13]. Experience from other countries/states with a DRS shows that they often improve the quality of material collected, as containers are generally cleaner and there is less contamination with non-target materials. Another benefit of the DRS is directly linked with landscape, as it has impact on the littering issues and a range of 
Packaging recycling rates within deposit-refund system. Created by the authors.

\begin{tabular}{|c|c|c|c|}
\hline \multirow{2}{*}{ Country } & DRS & $\begin{array}{c}\text { Deposit fee, Eur } \\
\text { per packaging }\end{array}$ & $\begin{array}{c}\text { Recycling } \\
\text { rate, } \\
\%\end{array}$ \\
\hline Germany & Aluminium, glass, plastic & 0.25 & 98.5 \\
\hline Norway & Aluminium, glass, plastic & $0.13-0.33$ & 95 \\
\hline Netherlands & Large plastic bottles, beer bottles, plastic beer crates & 0.25 & 95 \\
\hline Finland & Aluminium, glass, plastic & $0.15-0.40$ & 93 \\
\hline Denmark & Plastic, glass & $0.13-0.40$ & 89 \\
\hline Estonia & Aluminium, glass, plastic & 0.10 & 90 \\
\hline Sweden & Plastic, aluminium & $0.10-0.20$ & 85 \\
\hline Lithuania & Aluminium, glass, plastic & 0.10 & \\
\hline
\end{tabular}

Comparison of Lithuanian and Estonian DRS. Created by the authors.

\begin{tabular}{|c|c|c|}
\hline DRS & Estonia & Lithuania \\
\hline Types of packaging & PET, glass, metal $(>150 \mathrm{ml}<31)$ & PET, glass, metal $(>100 \mathrm{ml}<31)$ \\
\hline System operator & $\begin{array}{l}\text { Non-profit company established by } 4 \\
\text { associations of beverage producers and traders } \\
(25 \% \text { each). }\end{array}$ & $\begin{array}{l}\text { Non-profit company established } \\
\text { by } 3 \text { associations of beverage } \\
\text { producers and traders. }\end{array}$ \\
\hline $\begin{array}{l}\text { Remuneration paid } \\
\text { by the DRS operator } \\
\text { to the point of } \\
\text { acceptance of the } \\
\text { packaging }\end{array}$ & $\begin{array}{l}\text { 1) manually EUR } 0.0105 \text { per plastic packaging; } \\
\text { EUR } 0.00120 \text { per glass packaging; } \\
\text { 2) with a non-compression machine EUR } \\
0.0215 \text { per plastic packaging, EUR } 0.0234 \text { per } \\
\text { glass packaging; } \\
\text { 3) With a machine with compression EUR } \\
0.0310 \text { per plastic packing unit. }\end{array}$ & $\begin{array}{l}\text { 1) manually EUR } 0.015 \text { per } \\
\text { packaging; } \\
\text { 2) with a machine EUR } 0.028 \text { per } \\
\text { unit (including unit handling fee } \\
\text { of EUR } 0.016 \text {, since the machines } \\
\text { for receiving packaging do not } \\
\text { belong to merchants). }\end{array}$ \\
\hline Initial investments & (2005 prices) - EUR 15 million & (2016 prices) - EUR 30 million. \\
\hline Financing for DRS & \multicolumn{2}{|c|}{$\begin{array}{l}\text { Revenues: } \\
\text { 1) participation fees for beverage producers / traders; } \\
\text { 2) unsolicited deposit; } \\
\text { 3) profit from the sales of packaging for recycling/recovery. } \\
\text { Expenses: } \\
\text { 1) reward for merchants; } \\
\text { 2) costs for preparing of packaging for recycling/recovery; } \\
\text { 3) logistics costs; } \\
\text { 4) cost of reverse vending machines. }\end{array}$} \\
\hline
\end{tabular}

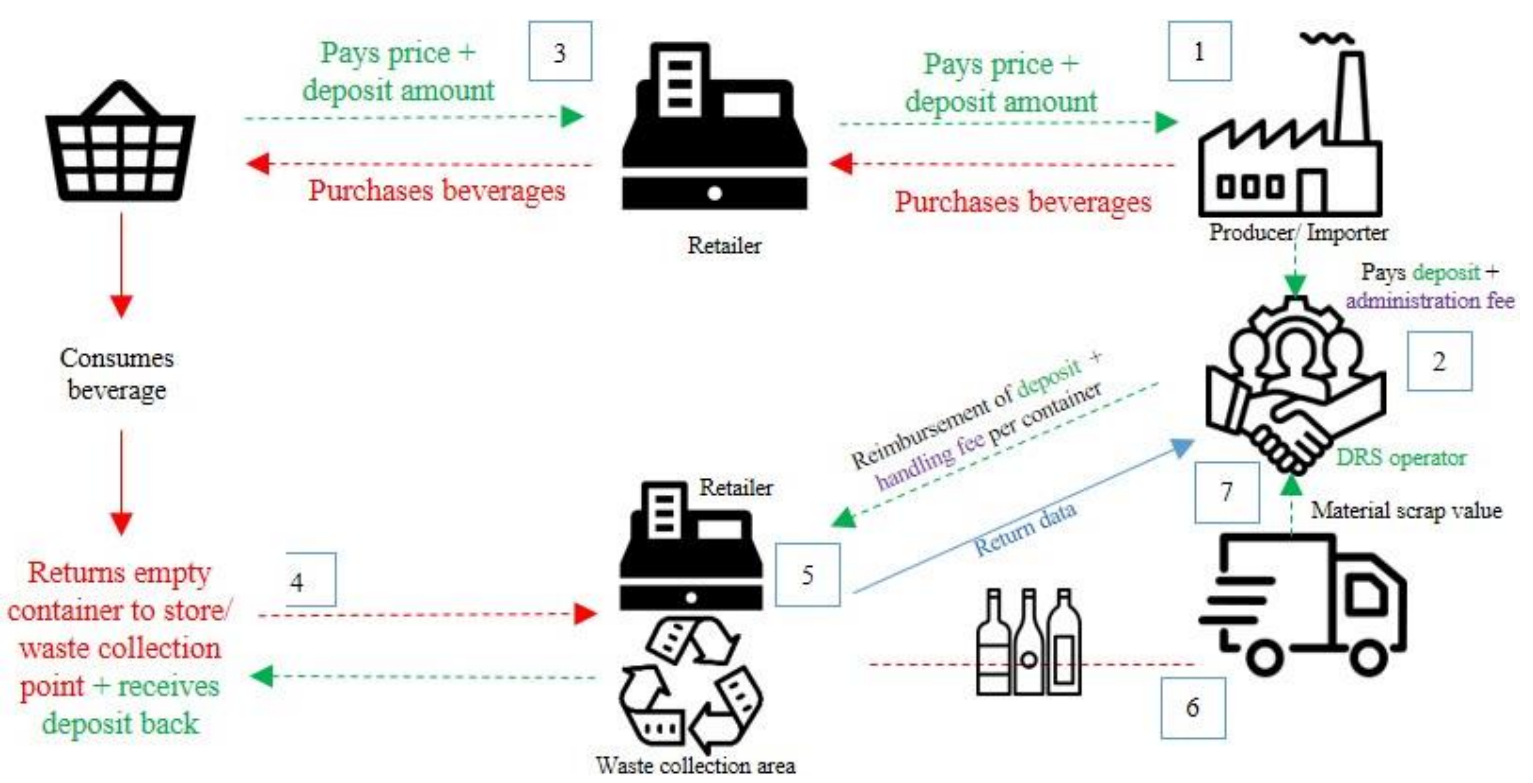

Fig. 2 Material and financial flow of potential Latvian DRS. Created by the authors, based on Reloop, 2018. 
countries, which have DRS in place, including in particular Estonia and Lithuania prove that the littering decreases significantly.

\section{Comparison of Estonian and Lithuanian DRSs}

In Estonia, mandatory DRS for beverage packaging (deposit system for single-use and reusable packaging was launched in 2005) was developed prior to sorted waste collection system. At that time, the producer responsibility systems also were not yet developed in Estonia.

In Lithuania, mandatory DRS for beverage packaging (deposit system for disposable packaging was launched in 2016) was developed when the country had already developed sorted waste collection system, had active producers' responsibility system companies, and a DRS for reusable glass packaging was already applied. Although the waste management

Deposit-refund schemes can be effective in redirecting waste streams from final disposal to reuse and recycling. The advantage of a deposit refund scheme is that it reduces the incentive for illegal dumping while it simultaneously stimulates reuse and recycling of products. In addition, it reduces the amount of waste [19]. The authors see DRS as a strong mechanism for significant decrease of environmental littering, thus bringing positive impact on landscape. Littering not only entails clean-up costs, but also has a negative impact on communities and businesses, moreover, an $80 \%$ reduction in litter is also assumed following implementation of the DRS. This is a conservative estimate based on a comparative review of the effect of DRSs on littering behaviour and on impact on the overall country landscape [6].

The DRS, even despite more complex implementation process, generally provides greater transparency and control over the operation of producer responsibility schemes and can be considered more cost-effective in the long term. It is highly debated, that the efficiency of beverage packaging DRS is doubtful, as it covers only a small part of the total packaging volume. However, this is an important contribution to the recycling targets of packaging waste. The authors see both systems (existing waste management and DRS) as complementary, not exclusive, because the types of packaging and materials not covered by the deposit system will be collected within sorted waste collection system. By application of the DRS, it is expected to have an indirect positive effect on the overall companies did not support the application of the DRS, they were given the opportunity to participate in the implementation of the deposit system by providing the service - ensuring the acceptance of the deposit package from consumers. The authors see it essential that the DRS will not be developed against existing system on the contrary, it will be able to amend and improve the existing system and have efficient use of the infrastructure. Following table provides a detailed comparison of Latvia's neighbouring countries with DRS in place. When evaluation the systems, developed by the neighbouring countries, the authors see that it is of vital importance to understand not only the implementation stage of the system, but also to develop the comprehensive representation of the packaging flow and financial flow within the DRS.

\section{Conclusions}

environmental awareness of the society by raising awareness of waste sorting and sorted waste collection. With the operation of the DRS - by accepting the deposit packaging from the consumers it is possible to use the sorted waste collection areas in local governments. With this the waste management companies could become involved in the DRS.

While assessing all the positive examples of Lithuania and Estonia, as well as other EU countries with DRS in place, the authors foresee that performance indicators after one year of the introduction of the beverage packaging deposit system, could ensure that $80 \%$ of the reusable beverage packaging sold is recovered; $60 \%$ of the recovered disposable beverage packaging is recycled or recovered; reduced litter size of forests, roadside and roadside $-75 \%$; The cost of cleaning forests, roadside and roadside parking is reduced by $25 \%$.

Overall it may be concluded, that taking into account the ambitious targets set by the European Commission, the authors see that currently it is the best possible timing for the implementation of the DRS, as it has to be taken into consideration that the implementation costs will not decrease over time.

When tackling the topic of further recommendations, in the context of the new Directive on single use plastics, the authors would advise to introduce ban on certain types of packaging as well on all types of plastic bags. This will also be assessed in more details in the further papers, developed by the authors.

\section{References}

1. COM. Proposal for a Directive of The European Parliament and of The Council on the reduction of the impact of certain plastic products on the environment [online]. Brussels, 28.5.2018 [cited 12.12.2018]. https://eur-lex.europa.eu/legalcontent/en/ALL/?uri=CELEX\%3A52018PC0340

2. Dace, E., Pakere, I., Blumberga, D. Evaluation of economic aspects of the deposit-refund system for packaging in Latvia. Management of Environmental Quality an International Journal, 2013, No. 24, p.311-329. DOI:10.1108/14777831311322631. 
3. European Environment agency. European refunding scheme for drinks containers. Report, co-rapporteurs Mr. Nikolai Astrup and Ms. Anna Hedh [online]. Joint Parliamentary committee, 2011 [citerd 10.12.2018]. http://www.europarl. europa.eu/meetdocs/2009_2014/documents/deea/dv/2611_07_/2611_07_en.pdf

4. Ettlinger, S. DRS (and Packaging Tax) in Finland [online]. Eunomia, 2016 [cited 10.12.2018]. https://ieep.eu/uploads/articles/attachments/9d526526-d22b-4350-a5906ff71d058add/FI\%20Deposit\%20Refund\%20Scheme\%20final.pdf?v=63680923242

5. Hogg, D., Sherrington, Vergunst, T. A Comparative Study on Economic Instruments Promoting Waste Prevention: Final Report to Bruxelles Environnement [online]. Eunomia: research and consulting, 2011 [cited 06.12.2018]. http://document.environnement.brussels/opac_css/elecfile/Etude\%20dechets\%20Eunomia\%20Report\%20en

6. Hogg, D., Sherrington, Vergunst, T., Elliot, T. Impacts of a DRS on Local Authority Waste Services [online]. Eunomia: research and consulting, 2017. [cited 03.01.2019]. https://www.eunomia.co.uk/reports-tools/impacts-of-adeposit-refund-system-for-one-way-beverage-packaging-on-local-authority-waste-services/

7. Cordle, M., Elliott, L., Elliott, T., Kemp, S. Sherrington, C., Woods, O. A Deposit Refund System for the Czech Republic [online]. Eunomia: research and consulting, 2019 [cited 15.01.2019]. https://www.eunomia.co.uk/reportstools/deposit-refund-system-czech-republic/

8. Communication from the Commission - Beverage packaging, deposit systems and free movement of goods: COM 2009/C 107/01 [online]. European Commission, 2009 [cited 03.01.2019]. https://eur-lex.europa.eu/legal-content/ EN/TXT/?uri=CELEX\%3A52009XC0509\%2801\%29

9. Roadmap to a resource efficient Europe. Brussels 20.09.2011, coM (2011) 571 final [online]. European Commission, 2011 [cited 06.12.2018]. https://eur-lex.europa.eu/legal-content/EN/TXT/?uri=CELEX:52011DC0571

10. Report from the commission to the European Parliament, the council, the European economic and social committee and the committee of the regions, 2018. $\operatorname{COM(2018)~} 656$ final [online]. European Commission [cited 07.01.2019.]. http://ec.europa.eu/environment/waste/framework/early_warning.htm

11. Waste data statistics 2018 [online]. Eurostat, 2018 [cited 06.12.2018.]. http://ec.europa.eu/eurostat/web/waste/data/database, dataset (env_wasmun)

12. Estonian environment Information Center. Estonian Environmental Review 2009. Estonian Environment Information Centre, 2010. ISSN 1736-3373 [cited 03.01.2019]. https://www.keskkonnaagentuur.ee/publications/4266_PDF.pdf

13. Voluntary \& Economics Incentives Working Group Report. Voluntary and economic incentives to reduce littering of drinks containers and promote recycling [online]. DEFRA, UK, 2018 [cited 10.12.2018]. https://assets.publishing. service.gov.uk/government/uploads/system/uploads/attachment_data/file/694916/voluntary-economic-incentives-working -group-report-drinks-containers-final.pdf.

14. Schneider, J., Karigl, B., et.al. A European Refunding scheme for drinks containers (Briefing paper) [online]. Luxembourg, European Parliament, DG EXPO, 2011 [cited 08.12.2018]. http://www.europarl.europa.eu/RegData/ etudes/note/join/2011/457065/IPOL-AFET_NT(2011)457065_EN.pdf

15. Fletcher, D., Hogg, D., von Eye, M., Elliott, T., Bendali, L. Examining the Cost of Introducing a DRS in Spain. Final report for Retorna [online]. Eunomia, 2018. [cited 08.12.2018.]. https://www.eunomia.co.uk/reports-tools/examining-thecost-of-introducing-a-deposit-refund-system-in-spain/

16. Hassi, S., Pietkäinen, S. Creating an EU-wide deposit system for bottles and cans [online]. European Parliament. Parliamentary questions, 23. May 2011 [cited 03.01.2019.]. http://www.europarl.europa.eu/sides/getDoc.do?pubRef=//EP//TEXT+WQ+E-2011-005039+0+DOC+XML+V0//EN.

17. Kulshreshtha, P., Sarangi, S. "No return, no refund": an analysis of deposit-refund systems. Journal of Economic Behavior \& Organization, 2001, Vol. 46(4), p. 379-394.

18. Lavee, D. Acost-benefit analysis of a deposit-refund program for beverage containers In Israel. Waste Management, 2010, Vol. 30(2), 338-345. https://doi.org/10.1016/j.

19. Linderhof, V., Oosterhuis, F. H., Beukering, P. J. H. van, Bartelings, H. Effectiveness of deposit-refund systems for household waste in the Netherlands: Applying a partial equilibrium model. Journal of Environmental Management, 2019, Vol. 232, p. 842-850.

20. Mrozek, J. R. Revenue neutral deposit/refund systems. Environmental and Resource Economics, 2000, Vol. 17(2), p. $183-193$.

21. Numata, D. Policy mix in deposit-refund systems - From schemes in Finland and Norway. Waste Management, 2016, Vol. 52, p. 1-2.

22. Oosterhuis, F., Papyrakis, E., Boteler, B. Economic instruments and marine litter control. Ocean \& Coastal Management, 2014, Vol. 102, p. 47-54.

23. Kaikki kiertää. Palpan vuosi 2015 [PALPA annual report 2015] Suomen Palautuspakkaus Oy (PALPA), 2016. [cited 03.01.2019]. http://digipaper.fi/palautuspakkaus/128335/

24. Comments on: Mandatory Deposit Systems for One-Way Packaging [online] Pro Europe, 2012. [cited 08.12.2018]. http://www.pro-e.org/files/08 11_Position_Paper_Mandatory_Deposit_RBV01.pdf

25. Fact sheet: Deposit Return System: System Performance [online]. Reloop, 2017 [cited 08.12.2018]. http://reloopplatform.eu/wp-content/uploads/2017/09/Fact-Sheet-Performance-New2.pdf

26. Deposit systems for one-way beverage containers: global overview [online]. Reloop, 2018. [cited 08.12.2018.]. https://reloopplatform.eu/wp-content/uploads/2018/05/BOOK-Deposit-Global-27-APR2018.pdf

27. Schuyler, Q., Hardesty, B.D., TJ Lawson, Opie, K., Wilcox, C. Economic incentives reduce plastic inputs to the ocean. Marine Policy, 2018, Vol. 96, p. 250-255. ISSN 0308-597X.

28. Tomkevičiūte, G., Stasiškiene, Ž. Assessment of opportunities for beverage Waste Reduction by means of DepositRefund System. Environmental Research, Engineering and Management, 2006, Vol. 1(35), p. 61-72.

29. Walls, M. Deposit-Refund Systems in Practice and Theory. RFF Discussion Paper. Washington, DC: Resource for the Future, 2011, p. 11-47. 
30. Latvia: The Global competitiveness Index in detail. [online] World Economic Forum. Global Competitiveness Report 2012-2013, Geneva, Switzerland, p. 227 [cited 08.12.2018]. http://www3.weforum.org/docs/WEF_Global CompetitivenessReport_2012-13.pdf

INFORMATION ABOUT THE AUTHORS:

Natālija Cudečka-Puriṇa, Environmental Expert, Dr.sc.administr. (2018), Head of Division of Environmental Quality and Waste Management of the Ministry of Environmental Protection and Regional Development, Peldu street 25, LV-1494, Latvia. E-mail: natalija.cudecka@inbox.lv

Lilita Ābele, Environmental Expert, Mg.env.sc., lecturer at Faculty of Science and Engineering, head of Circular Economy Centre and director of master study programme Ecotehnologies at Liepaja University, Lielā 14, Liepaja, LV-3401, Latvia. E-mail: lilita.abele@liepu.lv

Dzintra Atstāja, Professor at the Department of Management and head of the Laboratory of Sustainability, Efficiency and Effectiveness at BA School of Business and Finance and researcher of the Circular Economy cCnter of Liepaja University (Latvia, Europa). E-mail: dzintra.atstaja@ba.lv

Vladimirs Cudečkis, Environmental Expert, Mg.sc. (1971), Mg.oec. (2000) lecturer at Faculty of Engineering, Economics and Management, Riga Technical University, Kalnciema street 6, LV-1048, Latvia. E-mail: vmc@inbox.lv

Kopsavilkums. Tieši pēdējās desmitgadēs ir krasi mainījusies sabiedrības informētība par atkritumu nepareizas apsaimniekošanas ietekmi uz cilvēku veselību un bioloǵisko daudzveidību. Piesārņojums rada būtisku kaitējumu ainavai un dabas videi. Ir svarīgi novērtēt esošos piesārņojuma avotus un censties tos ierobežot to rašanās avotā. Pēdējo gadu laikā Eiropas Savienība (ES) ir ievērojami nostiprinājusi atkritumu apsaimniekošanas prasības. Attiecībā uz jaunākajām dalībvalstīm tas nozīmē: pašreizējās sistēmas uzskaiti, standartiem neatbilstošu atkritumu poligonu slēgšanu un atjaunošanu, jaunas infrastruktūras izveidi, labāko pieejamo tehnologiju izmantošanu un, protams, dalītas atkritumu savākšanas sistēmas ieviešanu un attīstību. Pieaug prasības šķiroto atkritumu savākšanai. Raksta autori pamato vienu no risinājumiem - depozītu sistēmas ieviešanu. Pētījuma pamatā ir salīdzinošā novērtēšana un statistikas datu analīze. Pētîjuma rezultātā autori ierosina depozîta sistēmas īstenošanu kā labvēlīgu risinājumu gan Latvijas atkritumu apsaimniekošanā, gan kā instrumentu ainavas uzlabošanai no dabas vides aspekta. Atslēgas vārdi: depozīta sistēma, atkritumu apsaimniekošana un pārvaldība. 